\title{
MIT POLAKA ZA ATLANTYKIEM CZYLI SMUTNA (?) PRAWDA O ŻYCIU POLSKICH IMIGRANTÓW W STANACH ZJEDNOCZONYCH
}

\begin{abstract}
Zażdego roku tysiące Polaków bierze udział w loterii wizowej z 1 nadzieja wygrania biletu do lepszego świata - do Ameryki, gdzie nie ma biedy, gdzie benzyna tańsza jest niż woda, gdzie kupimy domek i będziemy robić barbecue... W Ameryce wreszcie będziemy mogli zaczaćc żyć jak ludzie. Wakacje na Florydzie, Boże Narodzenie z wielką, żywa choinka. W końcu, tak opowiada Wiesiek z Jadzią, też musimy, koniecznie musimy się tam dostać! Bo tam jest tak dobrze... Córka sasiada od trzech lat co wakacje jeździ dorabiać na campy ${ }^{1}$ i wraca z kupa pieniędzy, a w tym czasie to jeszcze paczki przysyła rodzicom! Jeśli nie uda się w tym roku, to może w następnym... Franek z Hela próbowali przez 7 lat. I teraz jak mają? W Nowym Jorku mieszkają! Tym, to się dopiero udało! - rozmawiaja podekscytowani rodzice czwórki dzieci z malutkiej wioski spod Rzeszowa. A jeśli się nie uda za rok? To może tak przez Meksyk, Kanadę spróbować? Nie, ta propozycja odpada. Za drogo. „Przewoźnikowi” trzeba zapłacić od 20 do 40 tysięcy złotych ${ }^{2}$. A kogo na to stać w dzisiejszych czasach...?
\end{abstract}

\footnotetext{
${ }^{1}$ Campy to prywatne ośrodki wypoczynkowe rodzin żydowskich, które spędzają tam lato. Zamożniejsze rodziny zabieraja ze sobą baby sitter i cleaning lady. Bardzo często są to studentki z Polski.

2 Opłaty tej wysokości pobieraja pośrednicy przy załatwianiu wizy lub fałszywych dokumentów. Cena zależy od rodzaju dokumentów i czasu potrzebnego na ich zdobycie.
} 
Podobnie do rodziny Państwa $\mathrm{X}$ z województwa podkarpackiego myśli wielu naszych rodaków. Marzy im się cudowna Ameryka, mlekiem i miodem płynąca. Bez nędzy, biedy, dziurawych ulic i starych sypiących się domów - takich jak ten, w którym od pokoleń mieszka ich rodzina. Nic dziwnego, że śnią o Ameryce, jak o krainie wiecznej szczęśliwości, z wytęsknieniem czekając na zaproszenie od rodziny, przyjaciół... Taki obraz zbudowała im w listach rodzina, przyjaciele, znajomi. Stworzyli mit, nierealny obraz państwa, gdzie każdemu jest dobrze, gdzie pracy jest pod dostatkiem, na wakacje lata się na Hawaje. Angielskiego, of course, nauczyć się bardzo łatwo..., a największym problemem jest zdobycie wizy - przepustki do raju i rozmowa ze Świętym Piotrem... na lotnisku. Ci biedni ludzie nie są świadomi, jak bardzo się mylą, jak bardzo rzeczywistość różni się od ich wizerunku budowanego przez lata w głowach na podstawie rozmów telefonicznych i paczek z tandetą za 99 cents...

Wielkie amerykańskie miasta, takie jak Nowy Jork czy Chicago, to także brud, hałas, smród, wszechobecny beton, spaliny i śmierdzące metro. Coś jednak każdego roku przyciaga tu miliony. Miasto niespełnionych, a zarazem zrealizowanych marzeń, ogromnych pieniędzy i wielkiej nędzy. Nowy Jork można kochać albo nienawidzić - mało, kto pozostaje wobec tego miasta obojętny. Kamienna dżungla Manhattanu i kaniony ulic u jednych wywołują klaustrofobię, u innych euforię. Co więc przyciaga tu „turystów”, „którzy spędzają tam - jak śpiewa lider zespołu El Dupa - przeciętnie osiem lat, mimo że jeszcze gdzieś indziej jest piękniejszy świat"4. Magnesem jest fakt, że Nowy Jork to stolica świata. Można tu znaleźć niemal wszystko. Dopiero na miejscu okazuje się, że prawdziwa Ameryka to nie tylko luksusowe samochody, olbrzymie posiadłości i drogie butiki.

W Stanach Zjednoczonych mieszka obecnie 31 milionów osób urodzonych za granica. Z tego 466 tysięcy to ludzie urodzeni w Polsce mówią dostępne od kilku tygodni na stronie internetowej dane Biura Spisu Powszechnego 5 . W statystykach tych nie są brani pod uwage nielegalni imigranci z całego świata, których liczbę Urząd Imigracyjny oblicza na 5-8 milionów. Nie uwzględniają one także Amerykanów polskiego pochodzenia urodzonych w Stanach Zjednoczonych. W 7 stanach ludność pochodzenia polskiego liczy w każdym $z$ nich ponad

\footnotetext{
${ }^{3}$ Sieć bardzo tanich sklepów, w których większość towaru można kupić za 99 centów.

${ }^{4}$ Fragment piosenki zespołu El Dupa pt. Natalia w Brooklynie odc. 1.

${ }^{5}$ Http:www.polonianews.com,17.12.2002.
} 
500 000, w kolejnych 10 stanach mieszka w każdym ponad 100000 Polaków ${ }^{6}$.

W Stanach Zjednoczonych mieszka ponad 9 milionów Polaków czy też Amerykanów polskiego pochodzenia, stanowią oni w tym kraju dziewiąta, co do wielkości grupę etniczna. Ponadto, według spisu powszechnego z 1990 r. liczba Polaków wzrosła o 1,1 miliona w ciagu dekady 1980-19907.

Dane spisu powszechnego (który przeprowadzany jest co dziesięć lat) z 2000 roku, mówią, iż trzema największymi skupiskami ludności polskiej w USA są takie stany, jak: Illinois (140 tyś. Polaków), Nowy Jork (93 tyś.) i New Jersey (55 tyś.). Na dalszych miejscach w tej demograficznej klasyfikacji znajdują się: Connecticut (25,5 tyś.), Floryda (24,9 tyś.), Kalifornia (24,6 tyś.), Michigan (15,3 tyś.), Massachusetts (134 tyś.), Pensylwania (11,9 tyś.) i Ohio (7,6 tyś.). Natomiast najmniejsza liczba Polaków mieszka w stanach: Wyoming (17), Missisipi (76), Dakota Południowa (88), Dakota Północna (93), Montana (251) i Idaho (310). $\mathrm{Na}$ egzotycznych Hawajach 291 mieszkańców to osoby urodzone w Polsce, a na mroźnej Alasce - $363^{8}$.

Pierwsza fala emigracji opuszczała Polskę na skutek antysemickiej polityki władz w 1968 roku i trwała do 1970 roku. W efekcie szykan, nagonki prasowej i zwolnień z pracy kraju wyjechało wówczas około 1220 tysięcy Polaków traktujących wyjazd jako skutek rozczarowania systemem. Kolejna grupa, określana mianem emigracji solidarnościowej, opuszczała kraj w latach osiemdziesiątych z przyczyn przede wszystkim ekonomiczno-politycznych. Emigracja związana z wprowadzeniem w grudniu 1981 roku stanu wojennego, stanowi tylko niewielką część całej grupy obliczanej na 1-1,3 miliona osób?

Duża generacja młodych imigrantów pojawiła się USA w latach 1980-1990 zamieniając niezbyt dostatnie życie w Polsce na marzenia o dobrobycie w amerykańskim stylu. Dla przykładu: liczba ludności w stanie Illinois wzrosła zaledwie o 0,03\% w ciagu dekady 1980-1990, podczas gdy liczba Polaków mieszkających w Illinois wzrosła w tym czasie o 7,9\% (do 962827 osób). Ostatnie 6 lat przyniosło także istotne zmiany w liczbie chicagowskiej Polonii. Ilość Polaków wzrosła ogromnie od czasu Spisu Powszechnego z 1990 r. Ponad 35000 imigrantów z Polski przyjechało do aglomeracji chicagowskiej ${ }^{10}$. Pozytywny jest w tym

${ }^{6}$ Tamże.

${ }^{7}$ Tamże.

8 Tamże.

${ }^{9}$ W. Roszkowski, Pótwiecze, PWN, 1997, s. 357.

10 Tamże. 
wszystkim fakt, że liczba polskich dzieci w programie dwujęzycznym, uczącym angielskiego, w szkołach publicznych wzrosła o $415 \%$ od 1989 r. ${ }^{11}$ Zarówno zasiedziali, jak i nowo przyjezdni przypomnieli sobie o języku urzędowym USA i przystąpili do nauki. Zgodnie z decyzją Sądu Najwyższego z 1982 roku wszystkie dzieci w USA, nawet jeśli ich rodzice przebywaja tu nielegalnie, maja prawo do korzystania ze szkolnictwa publicznego. Nie istnieje bowiem przepis odcinający drogę do edukacji dzieciom imigrantów ${ }^{12}$.

W latach 80. naszych rodaków z kraju wypędzały prześladowania na tle politycznym, więzienie, nieustanne poczucie zagrożenia, obawa przed wizytą nocnych gości w mundurach. Co zmusza dziś Polaków do podjęcia tak dramatycznej decyzji? Dlaczego tak wielu pcha się na Zachód rękoma i nogami? Dlaczego ludzie, aby dostać się do Ameryki, sa gotowi zostawić bliskich i wyruszyć w nieznane? Co sprawia, że wybieraja, często nieświadomie, amerykański koszmar i podejmują walkę o przetrwanie na obcym gruncie?

Dziś uciekaja przed bieda, bezrobociem i brakiem jakichkolwiek perspektyw i szans na poprawę swojego położenia. Czy kiedykolwiek zaczną wracać? Wielu młodych ambitnych ludzi jadących na studencka praktykę, staż, zdecydowanie deklaruje chęć powrotu. Ilu z nich zmieni zdanie lub będzie żyć w stanie samookłamywania się, że jeszcze tylko kilka tygodni, ewentualnie miesięcy, maksymalnie, w najgorszym wypadku rok i nareszcie do domu. A życie ucieka, a niedoszli powracający budzą się po sześćdziesiątce. Lecz wtedy nie ma się już zwykle do kogo wracać. Bo wszystko staje się jakieś obce i takie odległe...

Jak wygląda życie Polaków w Stanach? Wielu powodzi się nie najgorzej. Innym trudno związać koniec z końcem W Stanach poznałam ludzi, którzy żyją na nowojorskim Greenpoincie, na którym osiedliła się, jak wiadomo, największa polska grupa etniczna ${ }^{13}$. Od lat „zielone” wysyłaja żonom, mężom, dzieciom. Na studia, na utrzymanie domu... Często po raz ostatni widzieli swoich bliskich, gdy ci odprowadzali ich na lotnisko. No, ale ktoś musi się poświecić i utrzymywać rodzinę. Wynajmują jeden pokój, liczą tygodniówkę za tygodniówką skreślając dni w kalendarzu z nadzieja, że kiedyś uda im się wreszcie uzbierać tyle, aby godnie wrócić na stałe do Polski. Inna opcja polega na tym, że starają się ściagnąć rodzinę do siebie. Trwa to jednak latami, ponieważ o papiery trudno, a pośrednicy biorą dużo...

${ }^{11}$ K. Kowalska, Sezon na angielski, „Nowy Dziennik”, 25.09.2002, s. 4.

${ }^{12}$ M. Tomaszewski, Nielegalni mogq sie ucsyý, „Nowy Dziennik”, 25.09.2002, s. 4.

${ }^{13}$ K. Olechowski, Kominy symbolem Greenpointu?, „Nowy Dziennik”, 07.10.2002, s. 11. 
W wielu krajach, również $\mathrm{w}$ Polsce, popularne są loterie wizowe. Tysiące rodzin marzą o wylosowaniu wizy czy zielonej karty i wyjeździe do Ameryki na stałe. Większość z tych marzycieli nie zna dobrze języka angielskiego i nie ma żadnego zawodu. W internecie pojawiają się ogłoszenia zdesperowanych o treści: „Pomóżcie mi. Jak zdobyć wizę? Tradycyjne metody nie działaja (turystycznie, szkoła) Dzięki za odpowiedź” ${ }^{14}$. Doświadczeni „szczęśliwcy” służą radą: „Spróbuj w innym kraju. Ja w Meksyku, a potem w Wenezueli dostałem od ręki bez żadnych papierów z wyjątkiem paszportu. Pozdrawiam. Ale po cholerę chcesz tam jechać? Stany bardzo zaostrzyły kryteria otrzymania wizy, ale nawet jak ja otrzymasz, nie ma pewności, że Cię przepuszcza przez granicę. W 2002 roku prawie 500 Polaków zawrócono do Polski już na lotnisku w USA, mimo że mieli wizę. Więc ryzykujesz nawet jak dostaniesz wizę w innym kraju niż Polska. Zastanów się czy masz tyle pieniędzy na stracenie. Mimo wszystko Good Luck!!’. Pojawiają się też bardziej optymistycznie nastawieni doradcy: „Prawda, że jest tam teraz zwariowany okres dla emigrantów, ale nadal jest po co jechać!"15.

Siódmego października 2002 roku Amerykański Departament Stanu rozpoczął przyjmowanie zgłoszeń do najnowszej, corocznej edycji loterii wizowej DV-2004. Zbieranie zgłoszeń zakończyło się miesiąc później. Departament Stanu przewidział na rok budżetowy 2004 (rozpoczynający się 01.10.2003 roku) rozlosowanie 50 tysięcy wiz ${ }^{16}$. Mimo, że zaostrzono wymogi, jakie powinny spełniać zdjęcia wszystkich członków rodziny petenta, a w rozmowie z sekretarzem stanu Colinem Powellem minister spraw zagranicznych Włodzimierz Cimoszewicz poskarżył się na wysokie opłaty wizowe i złe traktowanie Polaków przy wjeździe do $\mathrm{USA}^{17}$, zainteresowanie loteria wizowa wcale nie zmalało. Jednak tylko 3500 osób z Polski mogło otrzymać wizę imigracyjną do USA. Obywatele żadnego z krajów biorących udział w loterii nie mogli bowiem przekroczyć $7 \%$ puli przyznawanych wiz ${ }^{18}$.

Co roku w Stanach Zjednoczonych lądują więc setki tysięcy imigrantów poszukujących szczęścia i dobrobytu. Czy Ameryka wciąż jest ziemią obiecaną dla odważnych i zaradnych przybyszów? Jak im się żyje w USA?

\footnotetext{
${ }^{14}$ Http:www.gazeta.pl/forum, 19.01.2003.

${ }^{15} \mathrm{Http}$ :www.polonianews.com/w-polonia/12-22.php, 19.01.2003.

${ }^{16}$ J. M. Szlechta., T. Deptuła, Rusza loteria wizowa, „Nowy Dziennik”, 07.10.2002, s. 1.

${ }^{17}$ Http:www.polonianews.com/w-polonia/12-22.php, 16.01.2003.

${ }^{18}$ M. Szlechta, dz. cyt., s. 5.
} 
Choć niektórzy mają w swojej Ojczyźnie ustabilizowane życie na niezłym poziomie licza, że w USA szybko będa jeszcze bogatsi. Jednak mało kto wie, że droga do dobrobytu mocno się tam wydłużyła.

„Zapytaj dziś przeciętnego Amerykanina, jak mu się żyło w latach 60. w Niemczech i Japonii. Powiedzą ci też o ile więcej można było kupić za wypłatę 15 lat temu. Ja przyjechałem do USA w połowie lat 70. i tylko z własnego doświadczenia widzę, jak bardzo spadł poziom życia w tym kraju, gdzie jeszcze nie tak dawno biedni byli tylko ci, którym się nie chciało wstać do pracy. Matki nie musiały pracować zawodowo, nikt nie słyszał o pracy na dwa etaty, ubezpieczenia i edukacja były bajecznie tanie (w porównaniu z dzisiejszymi, kosmicznymi cenami). Dodam do tego bardzo przystępne ceny real estate; samochody wręcz śmiesznie tanie w stosunku do zarobków. Dzisiejsza Ameryka, choć ciagle bogata, to jednak tylko cień tamtego kraju, który tak dobrze pamiętam. Nie mieliśmy tylu milionerów, co dzisiaj, to prawda, ale przecież bogaci ludzie poradzą sobie w każdym kraju. Mówią, że po wojnie prawie $40 \%$ całej produkcji przemysłowej było wytwarzanej w USA, przecież skądś to bogactwo musiało się wziąć, no nie? Ameryka to piękny i bogaty kraj, który wiele ma jeszcze do zaoferowania, ale proces upadku się już dawno zaczął i będzie ciagle trwać. Jeszcze do niedawna pogardzane przez Amerykanów prace teraz są trudne do zdobycia, mimo że ludzie ci maja wysokie kwalifikacje. Wasz obraz USA nikomu oprócz was samych nie zaimponuje. Proponuje się obudzić, optymizm jest dobry, ale nieusprawiedliwiony", napisał jeden z uczestników dyskusji na forum Polonia na stronach internetowych „Gazety Wyborczej”19.

Mirosław Pasek, który do Stanów przyjechał w 1977 roku i chodził na wykłady $z$ ekonomii na Uniwersytecie Harvarda ${ }^{20}$, od paru lat porównuje szanse emigrantów ćwierć wieku temu i obecnie. Niewykwalifikowany pracownik może dziś liczyć w USA na godzinną stawkę w wysokości 6-7 dolarów. Choć i tak najniższa ustalona przez rząd amerykański wynosi 5,15\$ na godzinę. Kwoty te sa wyższe w miastach takich jak Nowy Jork czy Chicago. Należy jednak pamiętać, że wraz ze wzrostem wynagrodzenia pną się w górę, niestety nieproporcjonalnie do zarobków, ceny mieszkań, żywności, komunikacji, benzyny, itp. Ćwierć wieku temu stawka robotnika wynosiła $4 \$$ za godzinę $e^{21}$ Emigrant bez zawodu może więc dziś zarobić niespełna dwukrotnie więcej niż w 1977 roku. Jednak w tym czasie koszty

\footnotetext{
${ }^{19} \mathrm{Http}: w w w . g a z e t a . p l /$ forum, 19.01.2003.

${ }^{20}$ G. Glowacki, Zanim siegnieszpo zielonq karte, „Głos Pomorza”, 10-12.01.2003, s. 22.

21 Tamże.
} 
utrzymania wzrosły aż kilkunastokrotnie. To, co dwadzieścia pięć lat temu wystarczało na godziwe życie i oszczędności w banku, teraz ledwie pozwala na zaspokojenie podstawowych potrzeb. Siła nabywcza dolara ćwierć wieku temu była trzykrotnie wyższa. Płace realne robotników maleją nadal z roku na rok. Dotyczy to także żyjących tam Polaków. Obecnie wielu polskich imigrantów jest zmuszonych opuścić Greenpoint, który zamieszkiwali od kilkunastu, kilkudziesięciu lat z powodu zbyt wysokich czynszów.

Poniżej, za Mirosławem Paskiem, przedstawiam tabelę, w której zestawione zostały koszty utrzymania w USA w 1977 roku i obecnie ${ }^{22}$.

\begin{tabular}{|l|r|r|}
\hline \multicolumn{2}{|c|}{ Koszty utrzymania w USA (w dolarach) } \\
\hline \multicolumn{2}{|c|}{1977 rok } & 2002 rok \\
\hline Pensja miesięczna pracownika niewykwalifikowanego & 700 & 1100 \\
& & \\
\hline $\begin{array}{l}\text { Miesięczny czynsz za mieszkanie w Bostonie } \\
\text { ( 4 pokoje z kuchnia) }\end{array}$ & 22000 & 200000 \\
\hline Cena tego mieszkania w budynku wielorodzinnym & 30000 & 250000 \\
\hline $\begin{array}{l}\text { Cena jednorodzinnego domu na przedmieściu Bostonu } \\
\text { (marzenie klas średnich) }\end{array}$ & 300000 & 2000000 \\
\hline Cena eleganckiego domu w dobrej dzielnicy Bostonu & 3999 & 12000 \\
\hline Najtańszy nowy samochód (w 1977 Chevy Chevette) & 1000 & 4000 \\
\hline Opłata za dzień w szpitalu ( z niewielkim zabiegiem) & 0,25 & 1,25 \\
\hline Jednorazowy przejazd metrem w Bostonie & 0,60 & 1,55 \\
\hline Galon benzyny (ok. 3,8 litra) & 23 & 60 \\
\hline Rachunek za prąd (500 kWh) & 0,56 & 0,80 \\
\hline Banany (kilogram) & 30 & 40 \\
\hline Tania uliczna prostytutka (pół godziny) & $15-45$ & $6-60$ \\
\hline Koszula męska & 10 & 1 \\
\hline Kalkulator & 2 & 4 \\
\hline Tanie piwo (za 6 butelek 0,33 l) & 4 & 5 \\
\hline Tanie wino (słodkie Porto firmy Taylor) & 0,50 & 1,49 \\
\hline Amerykański chleb-wata (niejadalny dla Europejczyków) & 1,50 & 2,80 \\
\hline Galon mleka (3,8 litra) & 0,40 & 0,90 \\
\hline Kilogram ziemniaków & & \\
\hline
\end{tabular}

Tak jak Polskę, tak i Amerykę dopadł kryzys gospodarczy niewidoczny jednak dla nas zza oceanu. Tam także ludzie narzekaja na

22 Tamże. 
brak pracy, w kraju, gdzie zawsze było jej pod dostatkiem. Przygnębiaja galopujące ceny mieszkań, żywności.

Dlaczego w USA żyje się coraz ciężej? Drożeje wszystko, z dobra praca jest coraz gorzej. Czy to powolny upadek kraju myszki Miki?

Są różne opinie na temat życia w Ameryce. Jednym powodzi się lepiej, inni ledwie przęda. Jak można przeczytać na przytaczanym już internetowym forum Gazety Wyborczej, Polacy różnie oceniają swoje położenie i możliwości: „Ja nie mogę narzekać. Doskonała praca, wspaniały klimat - nic, tylko żyć. USA jest wspaniałe dla tych, co chca, żeby było, a jak ktoś chce widzieć syf to nie ma problemu: 280 milionów ludzi, 3 strefy czasowe, 20 stopni szerokości geograficznej. Dziś na północnym wschodzie (NY State) - 33 stopni Fahrenheita, a w Los Angeles 80F. Każdy może wybrać, co chce. Praca? Dla chcącego nie ma nic trudnego, jak mówi przysłowie. Nieudacznicy ją strąca i nie potrafią znaleźć. Jeszcze raz: mnie żyje się tu doskonale!’23. „Wszędzie na świecie można żyć lepiej czy gorzej, oczywiście w USA o wiele łatwiej o tzw. dobra niż np. w Polsce, co nie znaczy ze USA są idealnym miejscem, i że w USA nie mam bubli albo niskiej jakości tzw. service"24.

Jak oceniają swoja sytuację Polacy mieszkający w Stanach? Opinie, jak zawsze, sa podzielone. Jak widać, można znaleźć zarówno zadowolonych jak i pesymistycznie nastawionych. Oto kolejne wypowiedzi naszych rodaków z Nowego Jorku: Wanda Woźniak z Greenpointu - pochodzi z Pisza, w USA od 17 lat: ,Jestem zadowolona. Po dziesięciu latach pracy dostałam emeryturę. W Polsce musiałabym na nią pracować dużo dłużej. Jestem zadowolona z życia, kocham Amerykę i zawsze mówię, że mam dwie Ojczyzny." Katarzyna Pleśniak z wypożyczalni X-PAT przy Manhattan Avenue - pochodzi z Rzeszowa, w USA od miesiąca: „Rzecza pozytywną był mój przyjazd do Ameryki. Jestem tu od 25 listopada, jeszcze nie wiadomo czy na stale. W Polsce moje życie było monotonne: uczelnia - dom - uczelnia - dom. Tutaj więcej się dzieje. Jestem zadowolona ze zmian". Dorota mieszka na Queensie, pochodzi z Krakowa, w USA od pół roku: „Podoba mi się w Nowym Jorku, dobrze się tu czuję, dostałam pracę, zadomowiłam się tutaj. W Polsce miałam trochę problemów, a tu wszystko zaczyna się od nowa". Wioletta i Andrzej Kamińscy - z College Point na Queensie, w USA od 8 lat, pochodzą z Suwałk: „Martwimy się tym, co się dzieje w gospodarce wzrostem cen, podwyżkami czynszu" ${ }^{25}$.

${ }^{23}$ Http:www.gazeta.pl/forum, 19.01.2003.

24 Tamże.

${ }^{25}$ K Kowalska., Jak byto w 2002 roku? Sondaż wśród mieszkańcón Greenpointu,, „Nowy

Dziennik", 31.12.2002, s. 10. 
Polakom w USA powodzi się różnie. Rozpiętość grup o różnym statusie społecznym jest bardzo szeroka - sięga od nizin po same szczyty. Dla tych, którzy czegoś się w Ameryce dorobili, zdobyli wykształcenie, pozycje, takie problemy jak szukanie pracy na budowie czy legalizacja pobytu są im dalekie i obce. Problemem staje się natomiast utrzymanie polskości, zachowanie tradycji, więzi z rodziną i Ojczyzną.

Autorzy bestselleru Sekrety amerykańskich milionerón szacują, że posiadacze milionowych fortun to w Stanach Zjednoczonych 3,5 proc. populacji. Wśród emigrantów, którzy wyjechali z Polski po wojnie, jest ich - proporcjonalnie do wielkości populacji - prawie trzy razy więcej! Próżno jednak, z drobnymi wyjątkami, szukać na naszej liście krezusów z polskimi korzeniami mieszkających poza USA. Dlaczego? Oddajmy głos komentatorowi „Chicago Tribune”: „Oni się chyba dobrze u nas czuja (...). Polacy są równie pomysłowi jak Żydzi, niemal równie oszczędni jak Szkoci, prawie tak samo pracowici jak Chińczycy. Dorzucając do tego wyniesiona z ojczyzny fantazję i upór, szybko - w stylu amerykańskich pionierów - zagospodarowuja swój nowy świat”26.

Takich Polaków rzeczywiści w Stanach nie brakuje. Świadczy o tym chociażby wydawana w Chicago polska biznesowa książka telefoniczna, która ma już ponad 1500 stron! Polacy coraz częściej opuszczaja getto Jackowa i osiedlają się w północno-zachodniej, najdroższej części Chicago. Nie gorzej radzą sobie w Nowym Jorku, o czym świadczą sukcesy Andrzeja Jańczyka, który zaliczany jest do grona potentatów na tamtejszym rynku nieruchomości. Polskie rezydencje znajdują się w Malibu, Naples, Vail i innych drogich miejscowościach w USA. Stowarzyszenie Właścicieli Hoteli i Moteli w Kolorado od lat zdominowali polscy górale. W ich rękach znajduje się ponad połowa tamtejszej bazy noclegowej. Franciszek Bobak buduje w Chicago własne supermarkety i nie może się nadziwić jak to możliwe, że w Polsce muszą je wznosić Francuzi czy Niemcy. Anatol Topolewski zatrudnia ponad 700 osób i sprzedaje swoje automaty przemysłowe w niemal każdym zakątku świata $^{27}$. Jaka jest recepta na sukces Bobaka i Topolewskiego? Praca, praca i jeszcze raz praca! Albo szczęście, jak w wypadku Zdzisława Wójtowicza, który wygrał na loterii ponad $18 \mathrm{mln}$ USD. Potem pomógł szczęściu i w ciagu ośmiu lat podwoił majątek. Rzecz jasna - dzięki pracy.

Prezydent Bush, spytany co myśli o Polonii amerykańskiej, odpowiedział: "Uważam, że największym wkładem Polski dla naszego

\footnotetext{
26 Tamże, 19.01.2003.

${ }^{27}$ Http:www.polonianews.com/w-polonia/12-22.php, 19.01.2003.
} 
kraju jest Polonia amerykańska: ludzie biznesu, ciężko pracujący,

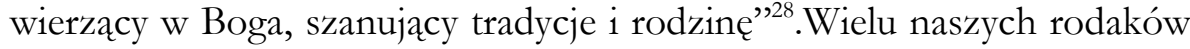
tworzyło bowiem amerykańską legendę from rags to riches - z łachmanów do bogactwa. Majątki zdobywali w większym trudzie niż większość bohaterów naszej listy 100 najbogatszych Polaków. Nie mogli liczyć na korzystne układy polityczne, na wsparcie państwa, nie mieli też szans na przejęcie za grosze prywatyzowanych przedsiębiorstw. Niemal każdy z wymienionych w rankingu emigrantów zaczynał od zera, najczęściej nie znając języka, nierzadko nie mając elementarnej wiedzy potrzebnej do prowadzenia biznesu w warunkach bezpardonowej konkurencji. Jan Kucharski najpierw założył mały zakład kuśnierski. Teraz ma największą w USA chłodnię. Andrzej Kolasa (góral z Nowego Targu) był mechanikiem w zakładach naprawczych, po dziewięciu latach morderczej pracy założył sklepik. Teraz ma sieć sklepów i buduje osiedle domów jednorodzinnych.

Nie wszystkim jednak się udało... Nie wszystkim życie płynie tak beztrosko i przyjemnie. Istnieją też tacy, którzy przegrywają walkę z samotnością, przeciwnościami losu... Bywa, że po kilku latach poddają się i lądują na ulicy. Zostają bumami, jak w USA nazywa się bezdomnych. Dane dotyczace 83529 mieszkańców Chicago, którzy mówią po polsku podają, iż 17,5\%, czyli 14643 osób żyje na lub poniżej poziomu ubóstwa, 47,4\% albo 39606 osób jest w wieku co najmniej 59 lat, wśród nich 3678 osób żyje na lub poniżej poziomu ubóstwa ${ }^{29}$. Ludzie ci zazwyczaj nie maja papierów, przebywaja w Stanach nielegalnie, na dodatek nie mówią po angielsku, więc nie są w stanie poszukać profesjonalnej pomocy. W Ameryce trzeba pracować, a niektórzy nie chca. Czasem opowiadaja jak kontraktorzy oszukiwali ich - bywało, że zamiast gotówką płacili alkoholem ${ }^{30}$. Bumy rzucają cień na reputację tych, którzy ciężko pracowali na swoją pozycję i na to, aby żyć godziwie. Tam jednego dnia możesz być milionerem, a drugiego cały świat może zawalić ci się na głowę. A wtedy nie ma już przyjaciól, bo obowiązuje zasada, że każdy sam rozwiązuje swoje problemy. Jeśli tego nie potrafi - idzie do psychoanalityka. Przyjaciele bowiem nie są od „pocieszania”. Każdy ma za dużo własnych kłopotów na głowie. I nagle zostajesz sam. Sa jednostki, które nie potrafią tego znieść. Dlatego właśnie wartość i znaczenie powiedzenia: być u siebie i wśród swoich, wielu potrafi

\footnotetext{
28 Tamże, 16.01.2003.

${ }^{29}$ Tamże.

${ }^{30}$ J. M. Szlechta., Bum na będrożu, „Polityka”, 23.10.1999, s. 103.
} 
zrozumieć po latach spędzonych poza granicami kraju, szczególnie, gdy nie ma nikogo, komu można by zaufać, na kim można by się oprzeć.

Polacy przyjeżdżający do Ameryki zderzają się z innym światem, z innym modelem życia i doznają szoku. W Polsce ludzie żyją rodzinnie, blisko siebie, ze sobą, a w Ameryce każdy żyje dla siebie. „Masz sąsiada, z którym przez lata mówisz sobie, co najwyżej, good morning. Nieznajomość języka, brak poczucia przynależności do jakiejś grupy społecznej, brak korzeni, tęsknota za Ojczyzna - ale rozumiana w duchu mickiewiczowskim, jako coś swojego, mały kawałeczek ziemi, gdzie coś się przeżyło, a czego tutaj nigdy nie uda się powtórzyć - to wszystko sprawia, że niektórzy nie potrafią się tutaj odnaleźć. Więc wracaja albo stają się bumami" ${ }^{31}$, twierdzi jeden z polskich imigrantów z New Jersey.

Latem w Nowym Jorku pojawia się nie tylko duża liczba studentów z Polski, ale także ludzi po czterdziestce, którym udało się dostać wizę turystyczna i przyjechali na zarobek. Rodziny i kobiety wynajmują zwykle piwnice (oczywiście od Polaków), co jest surowo zabronione, lub malutkie pokoiki, w których nocuja po kilka osób. Przeciętne mieszkanie takich sezonowych turystów dorobkiewiczów, to wieloosobowe mieszkanie subwayowe ${ }^{32}$. Lato zwykle na Wschodnim Wybrzeżu jest upalne, a deszcze praktycznie nie pojawiaja się do połowy września, tak więc zdarza się, że mężczyźni, aby zaoszczędzić, zbieraja się w grupy i „biwakuja” przy opustoszałych fabrykach nad East River albo w opustoszałych domach i samochodach. Hydrant służy im za prysznic, stary karton za łóżko... Przyjechali na krótko, aby zarobić. Po co więc wynajmować pokój, za który nieuczciwy rodak skasuje cię podwójnie. Do pracy na budowie nie trzeba spełniać specjalnych wymogów wizualnych, tak więc nie ma co przepłacać. Taki jest tok rozumowania wielu. Smutne, ale jednak prawdziwe.

„Chcesz dobrze mówić po angielsku? Poznać ciekawych ludzi w ciekawych miejscach? Zarobić „kilka” dolarów? Zrobić pierwszy krok w swojej karierze? Wykorzystaj szansę, która Tobie dajemy!" 33 Zachęcaja kolorowe broszury, pokazując roześmiane twarze młodych przybyszów z całego świata. „Przyjedź do Ameryki i zmień swoje życie, spełnij marzenia..." Więc studenci i młodzi, zdolni ludzie jada poznać kolorowa, uśmiechnięta Amerykę, by zobaczyć lepszy świat. Czy rozczarowują się na miejscu? Nie. Najczęściej ląduja w ekskluzywnych (jak dla nich) hotelach, drogich restauracjach, kasynach. Często więc nie mają szansy

31 Tamże.

32 Nazwa pochodzi od angielskiego słowa subway - pociag; mieszkania te tworzą przejściowe pokoje przypominające wagony.

${ }^{33}$ Folder wydany przez firmę JDJ na rok 2003/2004. 
zderzyć się z prawdziwym obliczem kraju Myszki Miki. Gdy poznaja lepiej okoliczne dzielnice biedy, odrobinę prostuje się ich spojrzenie na krajobraz amerykańskiego świata z bajki. Ich okulary nie maja już tak intensywnego odcienia różu, jednak wciąż pozostaja na ich nosach, deformując rzeczywistość. Bowiem prawdziwą Amerykę wraz ze swoim brudem, karaluchami, dziurami w ulicach, upałem, hałasem i trudnościami $\mathrm{z}$ pracą spotykaja zwykle odważni szaleńcy $\mathrm{z}$ wiza turystyczną w kieszeni, jadący w ciemno. Snując się po dzielnicach, w których dominujący język zmienia się wraz z wkroczeniem do kolejnej tam dopiero można poznać ogromny kraju kontrastów, gdzie toczy się walka o każdego centa. Nie w wesołych miasteczkach i restauracjach w nadmorskich kurortach, do których najczęściej, jeśli firma z Polski ich nie „wystawi”, lądują studenci.

Studentki, i nie tylko, przyjeżdżaja na wakacje do Stanów, aby pracować na campach, jako baby sitter czy cleaning leady. Młode kobiety jada często same na 2, 3 lata wysyłane przez mężów. Zostawiają w domach malutkie dzieci i wyruszając na poszukiwanie pracy za Oceanem. Studentki można spotkać w Nowym Jorku. Lecz nie wszystkie pracuja sprzątając u żydowskich czy włoskich rodzin. Lepsza praca to posada kelnerki czy barmanki w luksusowej knajpie na Manhattanie. Takie oferty też się zdarzają. Warto jednak wiedzieć, że w Ameryce nie ma nic za darmo. Z tego każdy przybysz bardzo szybko musi zdać sobie sprawę. Tak zwani „prawdziwi” Amerykanie, czyli ci, którzy mieszkają tam od kilku pokoleń, są zabezpieczeni finansowo i maja szerokie znajomości, często pomagają. Nowy Jork jest jednak bardzo charakterystycznym miastem. Tam większość to przyjezdni, którym nikt nie pomagał, którzy nadal muszą walczyć o swoją pozycję. Dlaczego Latynosi, Włosi, Rosjanie, Arabowie, czy Hindusi mieliby tak po prostu za darmo pomóc obcemu, skoro moga to zrobić za odpowiednia opłata. A skoro dziewczyna dopiero co przyjechała i niewiele ma to... można to załatwić na innej zasadzie... Co jest w tym najbardziej przygnębiające? Że młode Polki bardzo chętnie idą na taka „ugodę”...

Dlatego każdy Polak w Ameryce stara się być samodzielny i samowystarczalny. Na co dzień w polskiej społeczności obowiązuje niepisana zasada: każdy sobie rzepkę skrobie. Gorzej bywa z powiedzeniem: „Jak ci Polak nie zaszkodzi, to już ci pomógł”. To przerażające zdanie usłyszałam $\mathrm{w}$ drugim tygodniu mojego pobytu za szeroka wodą od pięćdziesięcioletniej Litwinki przebywającej w Stanach od ponad roku. Niestety w późniejszym okresie zdarzało mi się słyszeć tą sentencję dosyć często. Najsmutniejsze jednak w tym wszystkim było to, że w wielu przepadkach okazała się ona prawdziwa. 
Skapi i mało uczynni Polacy, którzy nie pomogą, z drugiej strony potrafia, jak nigdzie - na emigracji, zjednoczyć się. Doskonałym wyrazem tego jest organizowana co roku na jesieni, słynna w Nowym Jorku i nie tylko, Parada Pułaskiego, czyli manifestacja polskości na Piątej Alei Manhattanu.

„Wsicko tak samo jak u nas, tylko owiec nie ma”34 - porównywał polskie góry i Nowy Jork młody góral z Podhala. To, czy Nowy Jork przypomina Tatry, pozostaje kwestia otwarta, ale tego dnia na Manhattanie górali nie brakowało. Wszędzie powiewały biało czerwone flagi i słychać było „, W Sichlańskiej Dolinie” i oczywiście

„Góralu, czy ci nie żal”. W regionalnych strojach maszerowali górale i krakowiacy, w powietrzu śmigały ciupagi i kolorowe kubraki. W mundurach maszerowali harcerze, kombatanci i Liga Morska. Nie zabrakło też licznych grup studenckich reprezentujących swoje prestiżowe uczelnie. Dominowały marynarki w biało czerwone pasy. Weterani Armii Krajowej dumnie nieśli biało czerwone opaski na rękawach i sztandar powstańczy. Ulicami polskiej dzielnicy jeździły samochody specjalnie przyozdobione balonami, flagami narodowymi. Tego dnia przekonałam się, że Polacy naprawdę potrafią być razem. Szkoda tylko, że takich dni w roku jak ten październikowy w Nowym Jorku jest tak niewiele...

Podczas gdy w Polsce większa cześć społeczeństwa jest niezadowolona, jak wykazuja badania, narzeka na rząd, na Balcerowicza, na korupcje, biedę i bezrobocie, gdy człowiek jest zmuszony oddalić się od rodzinnych stron, opinia i uczucia wobec ojczyzny większości z nas ulegaja diametralnej zmianie. W USA nadal mamy świadomość tego, że w Polsce ciężko, ale mimo to chcemy wracać... Do rodziny, do dobrze znanego osiedla, czasem nieznośnego, wścibskiego sąsiada. Bo w Polsce zostało wszystko to, co tak bliskie sercu. Takie nasze, swojskie.

W każdym zakątku świata, w którym człowiek się znajdzie, będzie miał do czynienia z czymś, czego nie może w tym fragmencie świata zaakceptować. W USA nie ma bliskości między ludźmi, choć panuje tolerancja. Wszystko opiera się na formalnych regułach grzecznościowych. W Polsce sa (podobno) sprawy, które się wymienia z ludźmi, ci ludzie wchodzą do naszego życia, a my wchodzimy do ich życia. A tam to po prostu nie istnieje. Ameryka jest bardzo samotnym krajem. Tam każdy jest dla siebie, nie dla kogoś. Nie ma czasu na przyjaźń, miłość. Praca, praca, jeszcze raz praca...

${ }^{34}$ M. Szczepański, Polska Piata Aleja, „Nowy Dziennik”, 07.10.2002, s. 1. 
Krzysztof Pieczyński, który w Stanach spędził 10 lat, w jednym ze swoich wywiadów przyznał: „Ameryka to bardzo smutny kraj”, Z pwenością, co niektórym z nas przydałby się taki wyjazd. Może tam potrafiliby docenić skromne, ale własne podwórko.

Praca została napisana na podstawie pięciomiesięcznego pobytu w Stanach Zjednoczonych, głównie w stanach Nowy Jork i New Jersey. Podczas pobytu miałam okazję bliżej przyjrzeć się i poznać lokalną społeczność polską wraz z jej słynną dzielnica Greenpoint. Spotykałam się z ludźmi pochodzącymi z najróżniejszych grup społecznych i reprezentujących przeciwstawne grupy zawodowe. Byli to ludzie, którzy skończyli w Stanach Zjednoczonych studia, mają doskonałą pracę i osiągnęli w życiu sukces. Przedstawiciele tej grupy, z którymi mogłam osobiście porozmawiać, byli jednak nieliczni. W głównej mierze napotkani przeze mnie „szczęśliwi imigranci” to ubodzy pracownicy fizyczni, żyjący często w bardzo kiepskich warunkach, którzy po dwudziestu latach pobytu ograniczają swoją znajomość języka angielskiego do zwrotów grzecznościowych, a $\mathrm{i}$ to w niektórych przypadkach stanowi problem. Jak mówią dane Urzędu Imigracyjnego, Polacy stanowia największą grupę etniczną w Chicago wśród słabo znających angielski osób starszych pomimo, że 88\% Polaków w starszym wieku posiada obywatelstwo amerykańskie. Oto dane dotyczące osób, co najmniej 60-letnich: 49559 Polaków, 32541 Latynosów, 18773 Włochów, nie znający urzędowego języka USA ${ }^{36}$.

Liczna grupa, z którą miałam możliwość obcować, stanowili studenci, którzy już nigdy nie zamierzają powrócić do Polski lub tacy, którzy są jak ci, pozostający tam od dwudziestu lat z zamiarem powrotu jutro (,Jaki dzień nie nadchodzi nigdy?” - pyta Coelho - „Jutro”). Chcąc jedynie odłożyć na mieszkanie, zebrać gotówkę, aby po powrocie w coś zainwestować itd., przeciagaja swój pobyt w nieskończoność. Byli też młodzi ludzie, którzy po piętnaście godzin na dobę, łącznie z weekendami, pracowali na budowach, w tanich knajpkach. Większość powróciła już zmęczona. Czy spełniona? Piosenka Kukiza i Piersi o

\footnotetext{
${ }^{35}$ J. Cegła, Ameryka to bardzo smutny kraj, „Głos Pomorza”, 03-05.01.2003, s. 20.
}

${ }^{36}$ Http:www.polonianews.com. 
torbie wypchanej dolarami staje się coraz mniej wiarygodna, szkoda jednak, że nie maleje wraz z tym jej popularność.

Ten, kto chce wyruszyć za Atlantyk zaślepiony amerykańskim mitem o dobrobycie, zapatrzony w przyjaciól, którym się udało, powinien koniecznie obejrzeć film Juliusza Machulskiego z 1997 roku Sacz̨śliwego Nowego Jorku, posłuchać piosenek chociażby zespołu El Dupa Natalia w Brooklynie czesść 1 i 2. Jeśli nie zmieni zdania i nadal myśli o emigracji i zarobieniu godziwych pieniędzy, to znaczy, że ma wykształcenie i dobry zawód. Tylko dla takich osób Ameryka będzie miała anielską twarz. Pozostali mogą wylądować w piekle. 